\begin{tabular}{|l|}
\hline 2. To: (Receiving organization) \\
Distribution \\
\hline 5. Proj./Prog./Dept./Div.: \\
Tank 24I-TY-102 \\
\hline
\end{tabular}

8. Originator Remarks: For Release
3. Fron: (Originating Organization) D. E. P1 ace, SESC, H5-27

6. Design Authority/ Design Agent/log. Engr.: MJ Kupfer gm 8/25197

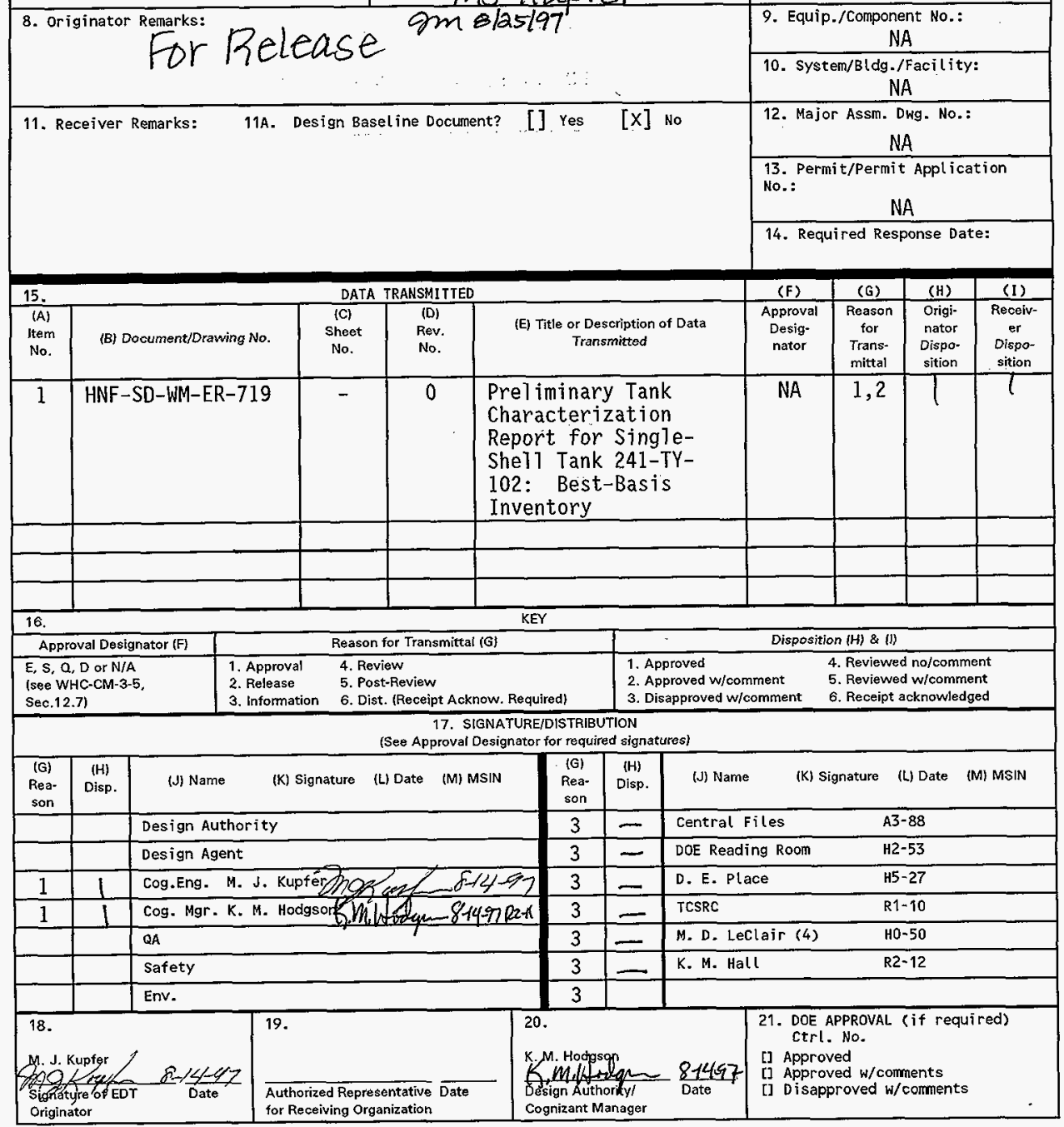

BD-7400-172-2(05/96) GEF097 


\section{Preliminary Tank Characterization Report for Single-Shell Tank 241-TY-102: Best-Basis Inventory}

\section{E: Place}

SGN Eurisys Services Corporation, Richland, WA 99352

U.S. Department of Energy Contract DE-AC06-96RL13200

EDT/ECN: 161463

Org Code: 74610

B\&R Code: EW3120074
UC: 712

Charge Code: N4G3A

Tota1 Pages: 3534

Key Words: TCR, best-basis inventory

Abstract: An effort is underway to provide waste inventory estimates that will serve as standard characterization source terms for the various waste management activities. As part of this effort, an evaluation of available information for single-shell tank 241-TY-102 was performed, and a best-basis inventory was established. This work follows the methodology that was established by the standard inventory task.

IRADEMARK DISCLAIMER. Reference herein to any specific commercial product, process, or service by trade name, trademark, manufacturer, or otherwise, does not necessarily constitute or imply its endorsement, recommendation, or favoring by the United States Government or any agency thereof or its contractors or subcontractors.

Printed in the United States of America. To obtain copies of this document, contact: Document Control Services, P.0. Box 950, Mailstop H6-08, Richland WA 99352, Phone (509) 372-2420; Fax (509) 376-4989.
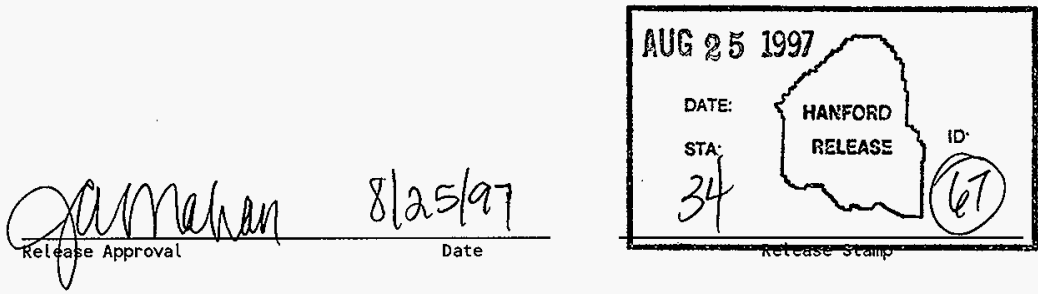


\title{
PRELIMINARY TANK CHARACTERIZATION REPORT FOR SINGLE-SHELL TANK 241-TY-102: BEST-BASIS INVENTORY
}

June 1997

\author{
D. E. Place \\ SGN Eurisys Services Corporation \\ Richland, Washington
}

Prepared for:

U.S. Department of Energy

Richland, Washington 
HNF-SD-WM-ER-719

Revision 0

This page intentionally left blank. 


\section{PRELIMINARY TANK CHARACTERIZATION REPORT \\ FOR SINGLE-SHELL TANK 241-TY-102: \\ BEST-BASIS INVENTORY}

This document is a preliminary Tank Characterization Report (TCR). It only contains the current best-basis inventory (Appendix D) for single-shell tank 241-TY-102. No TCRs have been previously issued for this tank, and current core sample analyses are not available. The best-basis inventory, therefore, is based on an engineering assessment of waste type, process flowsheet data, early sample data, and/or other available information.

The Standard Inventories of Chemicals and Radionuclides in Hanford Site Tank Wastes (Kupfer et al. 1997) describes standard methodology used to derive the tank-by-tank best-basis inventories. This preliminary TCR will be updated using this same methodology when additional data on tank contents become available.

\section{REFERENCE}

Kupfer, M. J., A. L. Boldt, B. A. Higley, K. M. Hodgson, L. W. Shelton, and R. A. Watrous (LMHC), S. L. Lambert, and D. E. Place (SESC), R. M. Orme (NHC), G. L. Borsheim (Borsheim Associates), N. G. Colton (PNNL), M. D. LeClair (SAIC), R. T. Winward (Meier Associates), and W. W. Schulz (W'2 Corporation), 1997, Standard Inventories of Chemicals and Radionuclides in Hanford Site Tank Wastes, HNF-SD-WM-TI-740, Rev. 0, Lockheed Martin Hanford Corporation, Richland, Washington. 
HNF-SD-WM-ER-719

Revision 0

This page intentionally left blank. 
HNF-SD-WM-ER-719

Revision 0

\section{APPENDIX D}

\section{EVALUATION TO ESTABLISH BEST-BASIS INVENTORY FOR SINGLE-SHELL TANK 241-TY-102}


HNF-SD-WM-ER-719

Revision 0

This page intentionally left blank.

D-2 
HNF-SD-WM-ER-719

Revision 0

\section{APPENDIX D \\ EVALUATION TO ESTABLISH BEST-BASIS INVENTORY FOR SINGLE-SHELL TANK 241-TY-102}

An effort is underway to provide waste inventory estimates that will serve as standard characterization source terms for the various waste management activities (Hodgson and LeClair 1996). As part of this effort, an evaluation of available information for single-shell . tank 241-TY-102 was performed and a best-basis inventory was established. This work, detailed in the following sections, follows the methodology that was established by the standard inventory task.

\section{D1.0 CHEMICAL INFORMATION SOURCES}

Available chemical and radiological inventory estimates for tank 241-TY-102 consist only of the inventory estimate generated by the Hanford Defined Waste (HDW) model (Agnew et al. 1997a). No Tank Characterization Report (TCR) has been previously issued for this tank, and recent (post 1989) core sample analyses are not available. However, analytical results are available for a core sample taken from tank 241-TY-102 in 1985 (Weiss and Mauss 1987a). The tank 241-TY-102 best-basis inventory, therefore, is based primarily on the 1985 core sample, augmented with the HDW model predictions and composition data from other Hanford Site tanks containing similar waste types.

\section{D2.0 COMPARISON OF COMPONENT INVENTORY VALUES}

The tank 241-TY-102 chemical and radionuclide inventory predicted by the HDW model (Agnew et al. 1997a) is provided in Table D2-1. The chemical species are reported without charge designation per the best-basis inventory convention. The HDW model inventory is based on $242 \mathrm{~kL}$ ( $64 \mathrm{kgal}$ ) of salt cake produced by the $242-\mathrm{T}$ Evaporator. 
HNF-SD-WM-ER-719

Revision 0

Table D2-1. Hanford Defined Waste Model Prediction of Tank 241-TY-102 Inventory.

\begin{tabular}{|c|c|}
\hline Analyte & Hanford Defined Waste model inventory $(\mathrm{kg})$ \\
\hline $\mathrm{Al}$ & 3,690 \\
\hline $\mathrm{Bi}$ & 391 \\
\hline $\mathrm{Ca}$ & 543 \\
\hline $\mathrm{Cl}$ & 1,060 \\
\hline $\mathrm{CO}_{3}$ & 3,830 \\
\hline $\mathrm{Cr}$ & 577 \\
\hline $\mathrm{F}$ & 383 \\
\hline $\mathrm{Fe}$ & 826 \\
\hline $\mathrm{Hg}$ & 0.362 \\
\hline $\mathrm{K}$ & 284 \\
\hline $\mathrm{La}$ & $1.49 \mathrm{E}-05$ \\
\hline $\mathrm{Mn}$ & 15.0 \\
\hline $\mathrm{Na}$ & 64,000 \\
\hline $\mathrm{Ni}$ & 115 \\
\hline $\mathrm{NO}_{2}$ & 10,000 \\
\hline $\mathrm{NO}_{3}$ & 95,000 \\
\hline $\mathrm{OH}$ & 14,900 \\
\hline $\mathrm{Pb}$ & 23.8 \\
\hline $\mathrm{PO}_{4}$ & 14,600 \\
\hline $\mathrm{Si}$ & 248 \\
\hline $\mathrm{SO}_{4}$ & 3,540 \\
\hline $\mathrm{Sr}$ & 0 \\
\hline TOC & 603 \\
\hline $\mathrm{U}$ & 2,090 \\
\hline $\mathrm{Zr}$ & 7.90 \\
\hline Radionuclide $^{a}$ & $\mathrm{Ci}$ \\
\hline${ }^{137} \mathrm{Cs}$ & 32,600 \\
\hline${ }^{90} \mathrm{Sr}$ & 9,990 \\
\hline
\end{tabular}

${ }^{a}$ Revision 4 of the Hanford Defined Waste model (Agnew et al. 1997a) contains estimates for 46 radionuclides. Only the two most prevalent ${ }^{90} \mathrm{Sr}$ and ${ }^{137} \mathrm{Cs}$ ) are listed in this table. The HDW model radionuclide predictions are baselined to January 1, 1994. 
HNF-SD-WM-ER-719

Revision 0

\section{D3.0 COMPONENT INVENTORY EVALUATION}

\section{D3.1 CONTRIBUTING WASTE TYPES}

The HDW model (Agnew et al. 1997a), the Sort on Radioactive Waste Type (SORWT) model (Hill et al. 1995) and the waste tank summary report (Hanlon 1997) are consistent as to the waste types present in tank 241-TY-102 and the total waste volume.

The HDW model (Agnew et al. 1997a) predicts that the tank contains $110 \mathrm{~kL}$ (29 kgai) of T1 salt cake (T1 SltCk), and $132 \mathrm{~kL}$ (35 kgal) of SMMT2 salt cake predicted from the Supernatant Mixing Model (SMM). The HDW model (Agnew et al. 1997a) refers to 242-T Evaporator salt cakes formed during 1951 to 1955 as T1 SltCk. The HDW model refers to 242-T Evaporator salt cakes formed during 1965 to 1976 as T2 SltCk on a global basis, or SMMT2 when calculated for an individual tank by the SMM.

The SORWT model (Hill et al. 1995) lists EB (evaporator bottoms), 1C (first decontamination cycle $\mathrm{BiPO}_{4}$ waste), and $\mathrm{MIX}$ (mixture of several miscellaneous supernatant wastes) as the primary, secondary, and tertiary waste types, respectively, but credits the entire tank $241-\mathrm{TY}-102$ volume ( $242 \mathrm{~kL}$ [64 kgal]) to salt cake with $53 \mathrm{~kL}$ (14 kgal) of interstitial liquid. Hanlon (1997) also indicates that the entire tank inventory is salt cake.

\section{D3.2 EVALUATION OF TECHNICAL FLOWSHEET INFORMATION}

Waste transaction records (Agnew et al. 1997b) show that tank 241-TY-102 initially received $530 \mathrm{~kL}(140 \mathrm{kgal})$ of $\mathrm{T} 1$ salt cake supernatant via the cascade overflow from tank 241-TY-101 in the fourth quarter of 1953. All but $87 \mathrm{~kL} \mathrm{(23)} \mathrm{kgal} \mathrm{of} \mathrm{this} \mathrm{supernatant} \mathrm{was}$ pumped to a crib in the third quarter of 1954 . Tank $241-\mathrm{TY}-102$ received $2,596 \mathrm{~kL}$ (686 kgal) of T1 salt cake supernatant from tank 241-TX-117 in the fourth quarter of 1954 , and $235 \mathrm{~kL}$ (62 kgal) of $242-\mathrm{T}$ Evaporator bottoms in the second quarter of 1955 . No further waste transfers were made into or out of tank 241-TY-102 until the third quarter of 1970. T1 salt cake would be expected to precipitate during this time period as the result of water evaporation and further cooling of the salt solution.

The waste transaction records (Agnew et al. 1997b) show that tank 241-TY-102 began receiving supernatant wastes from tank 241-TX-118 between the third quarter of 1970 and the second quarter of 1975 . These transfers were likely salt cake supernatants that were stored in tank 241-TY-102 to precipitate additional salt before recycle to the 242-T Evaporator. Anderson (1990) does not indicate that tank 241-TY-102 was designated as an evaporator bottoms receiver during this time period.

Because tank 241-TY-102 was not an evaporator bottoms receiver, formation of T2 salt cake in tank 241-TY-102 would have been limited to small quantities despite the large volume $(15,443 \mathrm{~kL}[4,080 \mathrm{kgal}])$ of solution that was received over the five year time 
period. The receipts were generally returned to the evaporator feed tank (241-TX-118), although one transfer of $613 \mathrm{~kL}$ (162 kgal) was made to tank 241-TX-101 in the first quarter of 1976.

Tank 241-TY-102 received $765 \mathrm{~kL}$ (202 kgal) of B Plant low-level waste (BL), Plutonium-Uranium Extraction (PUREX) organic wash waste (OWW), and Reduction-Oxidation (REDOX) ion exchange waste (RIX) supernatants from tank 241-TY-103 in the second quarter of 1973. Tank 241-TY-102 also received $102 \mathrm{~kL}$ (27 $\mathrm{kgal}$ ) of mixed supernatants from REDOX process high-level waste (R), U Plant uranium recovery wastes (TBP) and bismuth phosphate first cycle decontamination wastes (1C) from tank 241-TY-101 in the second quarter of 1974. Tank 241-TY-102 was later designated as a salt well receiver and received several smail transfers from tanks 241-TY-101, 241-TY-103, and 241-TY-104 in 1974 to 1976. The transfers from tanks 241-TY-103 and 241-TY-101 account for the 1C and MIX waste designations in the SORWT model (Hill et al. 1995).

Agnew et al. (1997b) indicates that salt well pumping of the tank 241-TY-102 interstitial liquid occurred in fourth quarter of 1983. Anderson (1990) does not report on events beyond 1980 .

\section{D3.3 DETERMINATION OF WASTE VOLUMES}

The HDW model estimates the T1 salt cake volume based on a solids volume measurement made in the fourth quarter of $1974(110 \mathrm{~kL}$ [29 kgal] of T1 salt cake). However, numerous transfers of T2 salt solutions had been made into the tank by that time. A solids level measurement made in the fourth quarter of 1969 (before the introduction of $\mathrm{T} 2$ salt solutions) indicated a solids volume of $114 \mathrm{~kL}$ ( $30 \mathrm{kgal}$ ), which is not significantly different from the volume used by the HDW model. A T1 salt cake volume of $110 \mathrm{~kL}$ ( $29 \mathrm{kgal}$ ) will be used for inventory calculations. The T1 salt cake supernatants and evaporator bottoms had been stored in tank 241-TY-102 for approximately 15 years, so the volume is reasonable.

Waste transaction records (Agnew et al. 1997b) show that tank 241-TY-102 received and temporarily stored a total of $15,443 \mathrm{~kL}(4,080 \mathrm{kgal})$ of $242-\mathrm{T}$ Evaporator salt solutions in 1970 to 1975 . The formation of a small quantity of salt cake in tank 241-TY-102 would be expected as the result of additional solution cooling. The HDW model volume of $T 2$ salt cake (132 kL [ $35 \mathrm{kgall})$ is calculated by subtracting the $\mathrm{T} 1$ salt cake volume from a June 28, 1982, solids volume measurement (Hanlon 1997). The resulting estimate of the T2 salt cake volume is $132 \mathrm{~kL}$ ( $35 \mathrm{kgal}$ ).

\section{D3.4 COMPOSITION OF TANK 241-TY-102 WASTE}

The tank 241-TY-102 waste composition can be estimated from the T1 and T2 salt cake compositions measured in other waste tanks. Estimation of the tank inventories based on the 
HNF-SD-WM-ER-719

Revision 0

$\mathrm{T} 1$ and $\mathrm{T} 2$ salt cake layers allows a comparison with the inventories calculated directiy from the 1985 composite core sample analyses of tank 241-TY-102 (Section D3.5), and provides estimates for analytes that were not included in the core sample analyses.

\section{D3.4.1 Composition of T1 Salt Cake}

Operation of the 242-T Evaporator between 1951 and 1955 resulted in 2,903 kL (767 kgal) of salt cake, which is contained in 10 underground storage tanks in the T, TX, and TY Tank Farms (Agnew et al. 1997a). The evaporator feeds during this time period consisted largely of $1 \mathrm{C}$ and TBP waste supernatants. The HDW model refers to this salt cake as T1 SltCk on a global basis. The HDW model uses this average T1 SltCk composition to calculate the T1 salt cake inventories for individual tanks rather than its SMM because of the lack of detailed evaporator feed composition data. The salt cake produced by the 242-T Evaporator from 1951 through 1955 will be referred to as T1 salt cake, hereafter, in this report. Seventy-nine percent of the T1 salt cake is contained in the TX Tank Farm. With the exception of tank 241-T-109, all tanks containing $\mathrm{T} 1$ salt cake also contain other waste types. Five of the tanks containing T1 salt cake have been core or auger sampled (tanks 241-T-108, 241-T-109, 241-TX-116, 241-TY-101, and 241-TY-102).

The auger samples for tanks $241-\mathrm{T}-108$ and $241-\mathrm{T}-109$ are recent (1995) and the laboratory analyses of the samples should meet all Tri-Party Agreement requirements. Tank 241-T-108 is expected to contain 1C/CW sludge as well as T1 salt cake (Agnew et al. 1997a); however, the analytical results indicate that the tank 241-T-108 sample retrieved was primarily salt cake as evidenced by the high sodium concentration $(223,000 \mu \mathrm{g} / \mathrm{g})$ reported for the composite (Baldwin 1996). Tank 241-T-109 contains only T1 salt cake generated from the 242-T Evaporator concentration of TBP and $1 \mathrm{C} / \mathrm{CW}$ supernatants. The composition of the tank 241-T-109 salt cake is not typical in that it is primarily sodium phosphate rather than sodium nitrate. The composition reported by the TCRs for tank 241-T-108 (Baidwin) and for tank 241-T-109 (Brown et al. 1996) are included in Table D3-1.

$\mathrm{T} 1$ salt cake was deposited in tank $241-\mathrm{TX}-116$ between 1951 and 1955 . The tank 241-TX-116 core sample was taken with the initial prototype of a rotary core sampler in 1976 to 1977 (Allen 1977). Sample recoveries were relatively poor and no material was recovered from several segments. Additionally, analytical methods and quality assurance requirements differed significantly from current practices. The analytical data are provided in a letter report (Horton 1977). Core segments 6, 7, 9, and 10 are expected to be T1 salt cake based on the HDW model layer volumes, and this is confirmed by differences in the core sample results as compared to segments 1 through 4 (T2 salt cake). No material was recovered in segments 5 and 8 . The analytical results were corrected to a silicon-free basis since diatomaceous earth ( 92 percent $\mathrm{SiO}_{2}$ ) was added to tank 241-TX-116 in November 1970, (Buckingham and Metz 1974). The analytical results are included in Table D3-1. 
HNF-SD-WM-ER-719

Revision 0

Table D3-1. Composition of T1 Salt Cakes. (2 Sheets)

\begin{tabular}{|c|c|c|c|c|c|c|}
\hline Analyte & $\begin{array}{c}\text { Tank } \\
241-\mathrm{T}-108 \\
(\mu \mathrm{g} / \mathrm{g})^{\mathrm{a}}\end{array}$ & $\begin{array}{c}\text { Tank } \\
241-\mathrm{T}-109 \\
(\mu \mathrm{g} / \mathrm{g})^{\mathrm{b}}\end{array}$ & $\begin{array}{c}\text { Tank } \\
241-\mathrm{TX}-116 \\
(\mu \mathrm{g} / \mathrm{g})^{\mathrm{c}, \mathrm{d}}\end{array}$ & $\begin{array}{c}\text { Relative } \\
\text { std dev } \\
\text { of mean } \\
(\%)\end{array}$ & $\begin{array}{l}\text { Average - } \\
\text { predicted } \\
\text { T1 salt } \\
\text { cake }(\mu \mathrm{g} / \mathrm{g})\end{array}$ & $\begin{array}{c}\text { HDW } \\
\text { model } \\
\text { T1 SltCk } \\
(\mu \mathrm{g} / \mathrm{g})^{\mathrm{f}}\end{array}$ \\
\hline $\mathrm{Ag}$ & $<7.96$ & 18.6 & NR & NA & $<13.3$ & NR \\
\hline $\mathrm{Al}$ & 2,290 & 1,250 & 1,720 & $17.2 \%$ & 1,750 & 140 \\
\hline $\mathrm{Bi}$ & 605 & 170 & NR & $56.1 \%$ & 388 & 1,807 \\
\hline $\mathrm{Ca}$ & 177 & 324 & NR & $29.3 \%$ & 251 & 2,117 \\
\hline $\mathrm{Cd}$ & $<7.96$ & $<5$ & NR & NA & $<5^{g}$ & NR \\
\hline $\mathrm{Cl}$ & $<905$ & 341 & NR & $\mathrm{NA}$ & $341^{g}$ & 1,377 \\
\hline $\mathrm{CO}_{3}$ & NR & 10,400 & 32,800 & $67.2 \%$ & 21,600 & 6,832 \\
\hline $\mathrm{Cr}$ & 19.2 & 40 & 150 & $58.3 \%$ & 69.9 & 129 \\
\hline $\mathrm{F}$ & 10,700 & 13,000 & 3,140 & $33.3 \%$ & 8,950 & 948 \\
\hline $\mathrm{Fe}$ & 6,110 & 5,490 & 16,000 & $37.0 \%$ & 9,200 & 4,041 \\
\hline $\mathrm{Hg}$ & NR & NR & NR & NA & NR & 0.601 \\
\hline $\mathrm{K}$ & $<239$ & $<500$ & NR & NA & $<239^{\mathrm{g}}$ & 270 \\
\hline $\mathrm{La}$ & $<39.8$ & $<\overline{50}$ & NR & NA & $<39.8^{g}$ & 0 \\
\hline $\mathrm{Mn}$ & 182 & 1,030 & NR & $70.0 \%$ & 606 & 0 \\
\hline $\mathrm{Na}$ & 223,000 & 181,000 & 246,600 & $8.85 \%$ & 216,900 & 185,810 \\
\hline $\mathrm{Ni}$ & $<15.9$ & $<20.0$ & NR & NA & $<18.0$ & 396 \\
\hline $\mathrm{NO}_{2}$ & 6,210 & 492 & 210 & $84.8 \%$ & 2,300 & 5,526 \\
\hline $\mathrm{NO}_{3}$ & 392,000 & 20,800 & 574,700 & $49.5 \%$ & 329,200 & 333,726 \\
\hline $\mathrm{OH}$ & NR & NR & NR & NA & NR & 8,933 \\
\hline $\mathrm{Pb}$ & 533 & 303 & $\mathrm{NR}$ & $27.5 \%$ & 418 & 0 \\
\hline $\mathrm{P}$ as $\mathrm{PO}_{4}$ & 125,000 & 246,000 & 13,500 & $52.4 \%$ & 128,200 & 70,614 \\
\hline $\mathrm{Si}$ & 1,500 & 889 & NA & $25.6 \%$ & 1,200 & 287 \\
\hline $\mathrm{S}$ as $\mathrm{SO}_{4}$ & 1,110 & 516 & 34,200 & $93.2 \%$ & 11,900 & 5,975 \\
\hline $\mathrm{Sr}$ & 21.6 & $<10$ & $\mathrm{NR}$ & NA & $<15.8$ & 0 \\
\hline TOC & NR & NR & NR & NA & NR & $\begin{array}{c}1.34 \mathrm{E}-04 \\
(\mathrm{wt} \%)\end{array}$ \\
\hline U & 1,130 & $<500$ & 0.0052 & NA & $<543$ & 9,724 \\
\hline $\mathrm{Zr}$ & 10.9 & 12.2 & NR & $5.63 \%$ & 11.6 & 19.2 \\
\hline
\end{tabular}

D-8 


\section{Revision 0}

Table D3-1. Composition of T1 Salt Cakes. (2 Sheets)

\begin{tabular}{|c|c|c|c|c|c|c|}
\hline $\begin{array}{l}\text { Radio- } \\
\text { nuclide }^{\mathrm{h}}\end{array}$ & $\begin{array}{c}\text { Tank } \\
241-\mathrm{T}-108 \\
(\mu \mathrm{Ci} / \mathrm{g})\end{array}$ & $\begin{array}{c}\text { Tank } \\
241-\mathrm{T}-109 \\
(\mu \mathrm{Ci} / \mathrm{g})\end{array}$ & $\begin{array}{c}\text { Tank } \\
241-\mathrm{TX}-116 \\
(\mu \mathrm{Ci} / \mathrm{g})^{\mathrm{a}}\end{array}$ & $\begin{array}{c}\text { Relative } \\
\text { std dev } \\
\text { of mean } \\
(\%)\end{array}$ & $\begin{array}{c}\text { Average - } \\
\text { predicted } \\
\text { T1 salt } \\
\text { cake } \\
(\mu \mathrm{Ci} / \mathrm{g})\end{array}$ & $\begin{array}{c}\text { HDW } \\
\text { model } \\
\mathrm{T} 1 \mathrm{SltCk} \\
(\mu \mathrm{Ci} / \mathrm{g})\end{array}$ \\
\hline${ }^{241} \mathrm{Am}$ & $<0.123$ & NR & NR & NA & $<0.123$ & 4.67 E-04 \\
\hline${ }^{60} \mathrm{Co}$ & $<0.0162$ & NR & NR & NA & $<0.0162$ & $5.77 \mathrm{E}-05$ \\
\hline${ }^{134} \mathrm{Cs}$ & NR & NR & 0.0080 & $\mathrm{NA}$ & 0.0080 & 2.43 E-06 \\
\hline${ }^{137} \mathrm{Cs}$ & 2.00 & NR & 3.2 & $40.7 \%$ & 2.6 & 34.4 \\
\hline${ }^{154} \mathrm{Eu}$ & $<0.0514$ & NR & NR & $\mathrm{NA}$ & $<0.0514$ & 0.00103 \\
\hline${ }^{155} \mathrm{Eu}$ & $<0.0503$ & NR & NR & $\mathrm{NA}$ & $<0.0503$ & 0.00496 \\
\hline $\begin{array}{l}\text { Density } \\
(\mathrm{g} / \mathrm{mL})\end{array}$ & $2.35^{i}$ & $1.55^{\mathrm{j}}$ & NR & $\mathrm{NA}$ & $1.7^{\mathrm{i}}$ & 1.74 \\
\hline$\% \mathrm{H}_{2} \mathrm{O}$ & $19.5 \%$ & $47.70 \%$ & NR & NA & $33.6 \%$ & $37.7 \%$ \\
\hline
\end{tabular}

HDW $=$ Hanford Defined Waste

$\mathrm{NR}=$ Not reported

$\mathrm{NA}=$ Not applicable

${ }^{2}$ Baldwin (1996)

${ }^{b}$ Brown et al. (1996)

' Horton (1977)

d Silicon-free basis due to the addition of diatomaceous earth to tank 241-TX-116

' Calculated from the mean analyte concentrations for the three tanks.

${ }^{f}$ Agnew et al. (1997a)

${ }^{g}$ Since these analytes were not expected in this waste, the lower less than value was used instead of an average.

${ }^{\mathrm{h}}$ All radionuclide concentrations are decayed to January 1, 1994

i The laboratory analysis for the tank $241-\mathrm{T}-108$ was a particle density measurement, rather than a bulk density. Therefore, the predicted density was arbitrarily set to $1.7 \mathrm{~g} / \mathrm{mL}$ to avoid over-reporting of the waste components.

${ }^{j}$ The density reported by the 241-T-109 TCR (Brown et al. 1996) was not actually measured, but based on a HDW model Revision 3 estimate. 


\section{Revision 0}

Tanks 241-TY-101 and 241-TY-102 were core sampled in 1985. As with the tank 241-TX-116 core sample, the analytical methods and quality assurance differed from current practices. Tank 241-TY-101 contains ferrocyanide scavenging wastes as well as salt cake. The relatively low sodium concentration reported for the composite $(121,000 \mu \mathrm{g} / \mathrm{g}$, Weiss and Mauss 1987b) indicates that the sample was primarily sludge and that the data are not appropriate examples of $\mathrm{T} 1$ salt cake. The sodium concentrations in salt cakes are typically near $200,000 \mu \mathrm{g} / \mathrm{g}$ (see Table D3-1). Tank 241-TY-102 contains both T1 and T2 salt cakes (about 45 percent $\mathrm{T} 1 \mathrm{salt}$ cake). Since only composite analyses were performed, the results can not be used as an example of T1 salt cake. The 1985 core sample data for tank 241-TY-102 will be used to calculate the overall tank chemical and radionuclide inventories (see Section D3.5).

The phosphate concentration for tank $241-\mathrm{TY}-102$ is relatively low $(29,000 \mu \mathrm{g} / \mathrm{g}$, Weiss and Mauss 1987a), indicating that the phosphate concentration of the $T 1$ salt cake added to tank 241-TY-102 could not have been comparable to concentrations measured for tanks 241-T-108 and 241-T-109 (125,000 and 246,000 $\mu \mathrm{g} / \mathrm{g}$, respectively, Table D3-1). Phosphate concentrations exceeding $100,000 \mu \mathrm{g} / \mathrm{g}$ are not necessarily typical of $\mathrm{T} 1$ salt cakes based on the analytical results for tanks 241-TY-102 and 241-TX-116. The reason for this wide variation in phosphate concentration is not known, but supernatants recycled from salt receiving tanks to the 242-T Evaporator might have been depleted in phosphate, and consequently the salt cakes formed from recycled supernatants would have a lower phosphate concentration.

The mean analytical data for tanks 241-T-108, 241-T-109, and 241-TX-116 are tabulated in Table D3-1. The relative standard deviation of the mean for all components except sodium and zirconium are extremely high, indicating that the composition of the waste type is extremely variable. The reason for the salt cake composition variability is not known, but the variations may be caused by differences in the fraction of $1 \mathrm{C}$ and TBP waste supernatants included in the evaporator feed and the recycle of salt cake supernatants. Any model which assumes that $\mathrm{T} 1$ salt cake has a relatively consistent composition, including the prediction in Table D3-1 or the HDW model (Agnew et al. 1997a), will have very limited usefulness in predicting the inventory of a tank containing $\mathrm{T} 1$ salt cake. The composition predicted by the HDW model for the global composition of $\mathrm{T} 1$ salt cake is included in Table D3-1 for comparison. With the exception of sodium and nitrate, the predicted T1 salt cake composition differs significantly from the HDW model T1 SltCk concentrations for most chemical analytes. The predicted $\mathrm{T} 1$ salt cake concentrations used to estimate the tark 241-TY-102 inventory for this evaluation will be based on the average of the concentrations in tanks 241-T-108, 241-T-109, and 241-TX-116.

The density reported for tank 241-T-108 is relatively high and reflects a particle density measurement, rather than a bulk density. The density of the predicted $\mathrm{T} 1$ salt cake was arbitrarily set to $1.7 \mathrm{~g} / \mathrm{mL}$ to avoid over-reporting of the waste components. T1 salt cake constitutes at roughly $45 \mathrm{vol} \%$ of the tank inventory, so the impact of the tank 241-T-108 high waste density could not be ignored. The selected value is in good agreement with the HDW model prediction for T1 salt cake. 
HNF-SD-WM-ER-719

Revision 0

\section{D3.4.2 Composition of T2 Salt Cake}

Post-1965 operation of the 242-T Evaporator resulted in $22,672 \mathrm{~kL}(5,990 \mathrm{kgal})$ of salt cake that is contained in 26 underground storage tanks in the S, SX, U, T, TX, and TY Tank Farms (Agnew et al. 1997a). The HDW model refers to this salt cake as T2 SltCk on a global basis or as SMMT2 when calculated by the SMM for an individual tank. The salt cake produced by the 242-T Evaporator from 1965 to 1976 will be referred to as T2 salt cake, hereafter, in this report. Ninety one percent of the T2 salt cake is contained in the TX Tank Farm. All tanks containing $\mathrm{T} 2$ salt cake also contain other waste types.

Eight tanks containing T2 salt cake have been core sampled (tanks 241-S-107, 241-U-102, 241-U-105, 241-U-107, 241-TX-107, 241-TX-116, 241-TY-102, and 241-TY-103). Only three of these tanks (241-U-102, 241-U-105 and 241-TX-116) have analytical data available at the core segment level and $\mathrm{T} 2$ salt cake layers large enough to differentiate it from other waste layers in the core sample data.

T2 salt cake was formed in tanks 241-U-102 and 241-U-105 from 1975 through 1976 (Agnew et al. 1997b). Core sampling of tanks 241-U-102 and 241-U-105 was performed in early 1996. Based on the HDW model, segments 4, 5, and 6 for the two cores from tank 241-U-102 and segment 8 of two cores from tank 241-U-105 are expected to be representative of the T2 salt cake waste type: An independent determination of these levels is not possible because of a lack of solids volume measurements in this time period. Furthermore, a significant composition change between the expected S2 salt cake and T2 salt cake layers can not be seen in the core sample data. The recent analytical data should meet all Tri-Party Agreement requirements. Descriptions of the core sampling events and analytical data for tanks 241-U-102 and 241-U-105 are available in the respective TCRs (Hu et al. 1997 and Brown and Franklin 1996).

T2 salt cake was deposited in tank 241-TX-116 between 1966 and 1971. The tank 241-TX-116 core sample was taken with the initial prototype of a rotary core sampler from 1976 to 1977 (Allen 1977). Sample recoveries were relatively poor. Additionally, analytical methods and quality assurance differed significantly from current practices. However, this sample event provides the only composition data for early production of the $\mathrm{T} 2$ salt cake waste type. Inclusion of an early T2 salt cake type is important since 242-T Evaporator feeds and operating practices changed over time.

The analytical data for tank 241-TX-116 are provided in a letter report (Horton 1977). Core segments 1 through 4 are expected to be representative T2 salt cake from the HDW model, and this is confirmed by vertical differences in the core sample results: It was necessary to correct the analytical results to a silicon-free basis because diatomaceous earth (92 percent $\mathrm{SiO}_{2}$ ) was added to tank 241-TX-116 in November of 1970 (Buckingham and Metz 1974). The diatomaceous earth had migrated into the top four core segments (approximately $203 \mathrm{~cm}$ [80 inches]) of the salt cake. 
The composition data for tanks 241-U-102, 241-U-105, and 241-TX-116 are summarized in Table D3-2. The analytical results for tanks 241-U-102 and 241-U-105 are mass-weighted averages based on the mass of the partial core segment corresponding to each analytical result. Mass-weighted averages, rather than simple arithmetic averages, were calculated because the core segments were not of equal length and the mass of the partial core segments analyzed varied from approximately $30 \mathrm{~g}$ to $250 \mathrm{~g}$. Similarly, a mass-weighted average was created for the combination of the T2 salt cake in the two $U$ Farm tanks (81.5\% tank 241-U-102 and $18.5 \%$ tank 241-U-105). The analytical results for tank 241-TX-116 core segments were simply averaged since the core segments were of equal length. The T2 salt cake prediction is the arithmetic average of the U Tank Farm and tank 241-TX-116 concentrations. The data for tank $241-T X-116$ were intentionally given more emphasis ( 50 percent of the predicted concentration) in the generalized $\mathrm{T} 2$ salt cake prediction as it represents an operating period that is more applicable to the TX Tank Farm. The global HDW model composition for T2 salt cake (T2 SltCk) is included in the Table D3-2 for comparison.

The use of the composition data from tanks 241-U-102, 241-U-105, and 241-TX-116 to represent the composition of other $T 2$ salt cakes should be viewed only as an approximation. None of these three tanks had undergone salt well pumping at the time of the respective core samples. In the case of tank 241-TY-102, these data are being applied to a salt cake which has been salt well pumped and has collapsed to a reduced volume as the result of the removal of interstitial liquid. Additionally, the T2 salt cake projected by the HDW model in tanks 241-U-102 and 241-U-105 could be erroneous if the transfers were TX Tank Farm supernatants (i.e., saturated salt solutions that had already cooled and would not form significantly more salt cake) rather than evaporator bottoms.

Table D3-2. Composition of T2 Salt Cakes. (3 Sheets)

\begin{tabular}{|c|c|c|c|c|c|c|}
\hline Analyte & $\begin{array}{c}241-\mathrm{U}-102 \\
\text { T2 salt cake } \\
\text { wt. avg.a,d } \\
(\mu \mathrm{g} / \mathrm{g})\end{array}$ & $\begin{array}{l}241-\mathrm{U}-105 \\
\text { T2 salt cake } \\
\text { wt. avg. }{ }^{\mathrm{a}, \mathrm{e}} \\
(\mu \mathrm{g} / \mathrm{g})\end{array}$ & $\begin{array}{c}\text { U tank farm } \\
\text { T2 salt cake } \\
\text { wt. avg. } \\
(\mu \mathrm{g} / \mathrm{g})\end{array}$ & $\begin{array}{c}241-\mathrm{TX}-116 \\
\text { T2 salt cake } \\
\text { mean }^{\mathrm{b}, \mathrm{f}} \\
(\mu \mathrm{g} / \mathrm{g})\end{array}$ & $\begin{array}{c}\text { T2 salt } \\
\text { cake } \\
\text { prediction } \\
(\mu \mathrm{g} / \mathrm{g})\end{array}$ & $\begin{array}{c}\text { HDW } \\
\text { T2 } \\
\text { SltCk } \\
(\mu \mathrm{g} / \mathrm{g})\end{array}$ \\
\hline $\mathrm{Ag}$ & 11.6 & 19.7 & 13.1 & NR & 13.1 & NR \\
\hline $\mathrm{Al}$ & 18,000 & 12,900 & 17,100 & 38,000 & 27,500 & 17,912 \\
\hline $\mathrm{Bi}$ & $<70.5$ & $<47.2$ & $<66.2$ & NR & $<66.2$ & 221 \\
\hline $\mathrm{Ca}$ & 308 & 253 & 298 & $\mathrm{NR}$ & 298 & 1,462 \\
\hline $\mathrm{Cd}$ & 5.94 & 12.8 & 7.21 & NR & 7.21 & NR \\
\hline $\mathrm{Cl}$ & 5,100 & 5,790 & 5,230 & $\mathrm{NR}$ & 5,230 & 3,328 \\
\hline $\mathrm{CO}_{3}$ & 53,500 & 36,500 & 50,300 & 58,000 & 54,200 & 17,093 \\
\hline $\mathrm{Cr}$ & 2,310 & 2,100 & 2,270 & 353 & 1,310 & 4260 \\
\hline$F$ & $<125$ & $1,110^{\circ}$ & $<307$ & 3,540 & $<1,920$ & 931 \\
\hline
\end{tabular}


HNF-SD-WM-ER-719

Revision 0

Table D3-2. Composition of T2 Salt Cakes. (3 Sheets)

\begin{tabular}{|c|c|c|c|c|c|c|}
\hline Analyte & $\begin{array}{c}241-\mathrm{U}-102 \\
\text { T2 salt cake } \\
\text { wt. avg.,d } \\
(\mu \mathrm{g} / \mathrm{g})\end{array}$ & $\begin{array}{c}\text { 241-U-105 } \\
\text { T2 salt cake } \\
\text { wt. avg. } \\
(\mu \mathrm{g} / \mathrm{g})\end{array}$ & $\begin{array}{c}\text { U tank farm } \\
\text { T2 salt cake } \\
\text { wt. avg. } \\
(\mu \mathrm{g} / \mathrm{g})\end{array}$ & $\begin{array}{c}241-\mathrm{TX}-116 \\
\text { T2 salt cake } \\
\text { mean }^{\mathrm{b}, \mathrm{f}} \\
(\mu \mathrm{g} / \mathrm{g})\end{array}$ & $\begin{array}{c}\text { T2 salt } \\
\text { cake } \\
\text { prediction } \\
(\mu \mathrm{g} / \mathrm{g})\end{array}$ & $\begin{array}{c}\text { HDW } \\
\text { T2 } \\
\text { SitCk } \\
(\mu \mathrm{g} / \mathrm{g})\end{array}$ \\
\hline $\mathrm{Fe}$ & 391 & 2,270 & 737 & 23,900 & 12,300 & 621 \\
\hline $\mathrm{Hg}$ & NR & NR & $\mathrm{NA}$ & NR & NA & 1.13 \\
\hline $\mathrm{K}$ & 1750 & 1,470 & 1,700 & NR & 1,700 & 1061 \\
\hline $\mathrm{La}$ & $<35.2$ & 29.7 & $<34.2$ & NR & $<34.2$ & 0.0001 \\
\hline $\mathrm{Mn}$ & 123 & 743 & 237 & NR & 237 & 160 \\
\hline $\mathrm{Na}$ & 262,600 & 220,500 & 254,800 & 166,700 & 210,800 & 192,764 \\
\hline $\mathrm{Ni}$ & 91.5 & 89.5 & 91.1 & NR & 91.1 & 406 \\
\hline $\mathrm{NO}_{2}$ & 56,700 & 40,100 & 53,600 & 7,840 & 30,700 & 46,096 \\
\hline $\mathrm{NO}_{3}$ & 284,700 & 395,700 & 305,200 & 308,700 & 306,950 & 268,197 \\
\hline $\mathrm{OH}$ & NR & NR & $\mathrm{NA}$ & 32,900 & 32,900 & 68,079 \\
\hline $\mathrm{Pb}$ & $<119$ & 214 & $<136$ & NR & $<136$ & 110 \\
\hline $\mathrm{P}$ as $\mathrm{PO}_{4}$ & 5,050 & 14,100 & 6,720 & 8,620 & 7,670 & 7,708 \\
\hline $\mathrm{Si}$ & 152 & 232 . & 167 & NA & 167 & 1,818 \\
\hline $\mathrm{S}$ as $\mathrm{SO}_{4}$ & 17,900 & 8,350 & 16,200 & 16,400 & 16,300 & 13,823 \\
\hline $\mathrm{Sr}$ & $<7.04$ & $<4.72$ & $<6.61$ & NR & $<6.61$ & 0 \\
\hline TOC & 8,810 & 11,000 & 9,210 & NR & 9,210 & $\begin{array}{l}0.519 \\
\text { (wt\%) }\end{array}$ \\
\hline $\bar{U}$ & $<353$ & 545 & $<388$ & NR & $<388$ & 2,174 \\
\hline $\mathrm{Zr}$ & 10.8 & 45.4 & 17.2 & NR & 17.2 & 14.7 \\
\hline $\begin{array}{l}\text { Radio- } \\
\text { nuclide }^{\bullet}\end{array}$ & $\begin{array}{c}241-\mathrm{U}-102 \\
\text { T2 salt cake } \\
\text { wt. avg. } \\
(\mu \mathrm{Ci} / \mathrm{g})\end{array}$ & $\begin{array}{c}241-\mathrm{U}-105 \\
\text { T2 salt cake } \\
\text { wt. avg. } \\
(\mu \mathrm{Ci} / \mathrm{g})\end{array}$ & $\begin{array}{c}\mathrm{U} \text { tank farm } \\
\text { T2 salt cake } \\
\text { wt. avg. }{ }^{2} \\
(\mu \mathrm{Ci} / \mathrm{g})\end{array}$ & $\begin{array}{c}241-\mathrm{TX}-116 \\
\text { T2 salt cake } \\
\text { mean }^{\mathrm{b}} \\
(\mu \mathrm{Ci} / \mathrm{g})\end{array}$ & $\begin{array}{c}\text { T2 salt } \\
\text { cake } \\
\text { prediction } \\
(\mu \mathrm{Ci} / \mathrm{g})\end{array}$ & $\begin{array}{c}\mathrm{HDW} \\
\mathrm{T} 2 \\
\mathrm{SltCk} \\
(\mu \mathrm{Ci} / \mathrm{g})\end{array}$ \\
\hline${ }^{241} \mathrm{Am}$ & $<37.0$ & $<0.95$ & $<30.3$ & $\mathrm{NR}$ & $<30.3$ & 0.0285 \\
\hline${ }^{60} \mathrm{Co}$ & $<0.155$ & 0.086 & $<0.142$ & $\mathrm{NR}$ & $<0.142$ & 0.027 \\
\hline${ }^{134} \mathrm{Cs}$ & NR & $\mathrm{NR}$ & $\mathrm{NA}$ & $9.64 \mathrm{E}-04$ & $9.64 \mathrm{E}-04$ & 0.0016 \\
\hline${ }^{137} \mathrm{Cs}$ & 197 & 145 & 188 & 34.8 & 111 & 163 \\
\hline${ }^{154} \mathrm{Eu}$ & $<0.475$ & 0.61 & $<0.499$ & $\mathrm{NR}$ & $<0.499$ & 0.431 \\
\hline${ }^{155} \mathrm{Eu}$ & $<1.10$ & 0.82 & $<1.05$ & NR & $<1.05$ & 0.185 \\
\hline
\end{tabular}


HNF-SD-WM-ER-719

Revision 0

Table D3-2. Composition of T2 Salt Cakes. (3 Sheets)

\begin{tabular}{|c|c|c|c|c|c|c|}
\hline $\begin{array}{c}\text { Radio- } \\
\text { nuclide }^{\mathrm{c}}\end{array}$ & $\begin{array}{c}241-\mathrm{U}-102 \\
\text { T2 salt cake } \\
\text { wt. avg. } \\
(\mu \mathrm{Ci} / \mathrm{g})\end{array}$ & $\begin{array}{c}241-\mathrm{U}-105 \\
\text { T2 salt cake } \\
\text { wt. avg. } \\
(\mu \mathrm{Ci} / \mathrm{g})\end{array}$ & $\begin{array}{c}\mathrm{U} \text { tank farm } \\
\text { T2 salt cake } \\
\text { wt. avg. } \\
(\mu \mathrm{Ci} / \mathrm{g})\end{array}$ & $\begin{array}{c}241-\mathrm{TX}-116 \\
\text { T2 salt cake } \\
\text { mean }^{\mathrm{b}} \\
(\mu \mathrm{Ci} / \mathrm{g})\end{array}$ & $\begin{array}{c}\text { T2 salt } \\
\text { cake } \\
\text { prediction } \\
(\mu \mathrm{Ci} / \mathrm{g})\end{array}$ & $\begin{array}{c}\mathrm{HDW} \\
\mathrm{T} 2 \\
\mathrm{SltCk} \\
(\mu \mathrm{Ci} / \mathrm{g})\end{array}$ \\
\hline $\begin{array}{c}\text { Density } \\
(\mathrm{g} / \mathrm{mL})\end{array}$ & 1.66 & 1.73 & 1.70 & $\mathrm{NR}$ & 1.70 & 1.63 \\
\hline
\end{tabular}

HDW = Hanford Defined Waste

$\mathrm{NA}=$ Not applicable

NR $=$ Not reported

${ }^{a}$ Weighted average based on the mass of each partial core segment analyzed.

b Silicon-free basis due to the addition of diatomaceous earth to tank 241-TX-116.

- Decayed to January 1, 1994.

${ }^{d} \mathrm{Hu}$ et al. (1977)

e Brown and Franklin (1996)

${ }^{f}$ Horton (1977)

${ }^{g}$ Average of U tank farm and tank 241-TX-116 data

${ }^{\text {h }}$ Agnew et al. (1997a) 


\section{Revision 0}

\section{D3.4.3 Tank 241-TY-102 Inventory Based on $\mathrm{T} 1$ and $\mathrm{T} 2$ Salt Cake Compositions}

The chemical and radionuclide inventory of tank 241-TY-102 can be estimated from the T1 salt cake, and T2 salt cake volumes $(110 \mathrm{~kL}$ [29 kgal], and $132 \mathrm{~kL}$ [35 kgal], respectively), density $(1.7 \mathrm{~g} / \mathrm{mL})$ and the average of chemical/radionuclide concentrations calculated for the 242-T Evaporator salt cake wastes that have been analyzed. The resulting chemical and radionuclide inventories are provided in Table D3-3.

Table D3-3. Predicted Tank 241-TY-102 Inventory Based on Salt Cake Layers.

(2 Sheets)

\begin{tabular}{|c|c|c|c|}
\hline Analyte & $\begin{array}{c}\text { T1 Salt } \\
\text { cake layer }^{\mathrm{a}} \\
(\mathrm{kg})\end{array}$ & $\begin{array}{c}\text { T2 Salt } \\
\text { cake layer }^{\mathrm{b}} \\
(\mathrm{kg})\end{array}$ & $\begin{array}{c}\text { Predicted 241-TY-102 } \\
\text { inventory } \\
(\mathrm{kg})\end{array}$ \\
\hline $\mathrm{Ag}$ & $<2.48$ & 2.95 & $<5.43$ \\
\hline $\mathrm{Al}$ & 327 & 6,200 & 6,530 \\
\hline $\mathrm{Bi}$ & 72.3 & $<14.9$ & $<87.2$ \\
\hline $\mathrm{Ca}$ & 46.7 & 67.0 & 114 \\
\hline $\mathrm{Cd}$ & $<0.933$ & 1.62 & $<2.56$ \\
\hline $\mathrm{Cl}$ & 63.6 & 1,180 & 1,240 \\
\hline $\mathrm{CO}_{3}$ & 4,030 & 12,200 & 16,200 \\
\hline $\mathrm{Cr}$ & 13.0 & 296 & 309 \\
\hline $\mathrm{F}$ & 1,670 & 433 & 2,100 \\
\hline $\mathrm{Fe}$ & 1,720 & 2,780 & 4,490 \\
\hline $\mathrm{K}$ & $<44.6$ & 382 & $<427$ \\
\hline $\mathrm{La}$ & $<7.43$ & $<7.70$ & $<15.1$ \\
\hline $\mathrm{Mn}$ & 113 & 53.4 & 167 \\
\hline $\mathrm{Na}$ & 40,500 & 47,500 & 87,900 \\
\hline $\mathrm{Ni}$ & $<3.35$ & 20.5 & $<23.9$ \\
\hline $\mathrm{NO}_{2}$ & 430 & 6,920 & 7,350 \\
\hline $\mathrm{NO}_{3}$ & 61,400 & 69,100 & 131,000 \\
\hline $\mathrm{OH}$ & 1,200 & 7,400 & 8,600 \\
\hline $\mathrm{Pb}$ & 78.0 & $<30.7$ & $<109$ \\
\hline $\mathrm{PO}_{4}$ & 23,900 & 1,730 & 25,600 \\
\hline $\mathrm{Si}$ & 223 & 37.6 & 261 \\
\hline $\mathrm{SO}_{4}$ & 2,230 & 3,670 & 5,900 \\
\hline
\end{tabular}


Table D3-3. Predicted Tank 241-TY-102 Inventory Based on Salt Cake Layers. (2 Sheets)

\begin{tabular}{|c|c|c|c|}
\hline Analyte & $\begin{array}{c}\text { T1 Salt } \\
\text { cake layer } \\
(\mathrm{kg})\end{array}$ & $\begin{array}{c}\text { T2 Salt } \\
\text { cake layer } \\
(\mathrm{kg})\end{array}$ & $\begin{array}{c}\text { Predicted 241-TY-102 } \\
\text { inventory } \\
(\mathrm{kg})\end{array}$ \\
\hline $\mathrm{Sr}$ & $<2.95$ & $<1.49$ & $<4.44$ \\
\hline $\mathrm{TOC}$ & $\mathrm{NR}$ & 2,070 & 2,070 \\
\hline $\mathrm{U}$ & $<101$ & $<87.4$ & $<189$ \\
\hline $\mathrm{Zr}$ & 2.16 & 3.87 & 6.03 \\
\hline & $\begin{array}{c}\text { T1 Salt } \\
\text { cake layer }\end{array}$ & $\begin{array}{c}\text { T2 Salt } \\
\text { cake layer } \\
(\mathrm{Ci})\end{array}$ & $\begin{array}{c}\text { Predicted } \\
241-\mathrm{TY}-102 \text { inventory } \\
(\mathrm{Ci})\end{array}$ \\
\hline${ }^{\mathrm{a}}{ }^{241} \mathrm{Am}$ & $<23.0$ & $<6,830$ & $<6,850$ \\
\hline${ }^{60} \mathrm{Co}$ & $<3.02$ & $<32.0$ & $<35.0$ \\
\hline${ }^{134} \mathrm{Cs}$ & 1.50 & 0.217 & 1.72 \\
\hline${ }^{137} \mathrm{Cs}$ & 491 & 25,000 & 25,500 \\
\hline${ }^{154} \mathrm{Eu}$ & $<9.59$ & $<112$ & $<122$ \\
\hline${ }^{155} \mathrm{Eu}$ & $<9.39$ & $<235$ & $<245$ \\
\hline Density & $1.7 \mathrm{~g} / \mathrm{mL}$ & $1.7 \mathrm{~g} / \mathrm{mL}$ & $1.7 \mathrm{~g} / \mathrm{mL}$ \\
\hline
\end{tabular}

${ }^{2}$ Based on the T1 salt cake prediction in Table D3-1

${ }^{b}$ Based on the T2 salt cake prediction in Table D3-2

' Radionuclides decayed to January 1, 1994.

\section{D3.5 COMPOSITION OF TANK 241-TY-102 BASED ON 1985 CORE SAMPLE}

A core sample was obtained from tank 241-TY-102 in September 1985 (Weiss and Mauss 1987a). The core consisted of two segments, with a reported average sample recovery of 78 percent as compared to the anticipated sample volumes. The analytical results for the core composite are provided in Table D3-4. The analytical methods and quality assurance differed significantly from current practices, however, the analytical data are the best that is currently available. The tank 241-TY-102 chemical and radionuclide inventories can be calculated directly from these analytical data based on the $242 \mathrm{~kL}$ $(64 \mathrm{kgal})$ total waste volume and the measured bulk density $(1.88 \mathrm{~g} / \mathrm{mL})$. The calculated inventories are also provided in Table D3-4. 
HNF-SD-WM-ER-719

Revision 0

Table D3-4. Composition of Tank 241-TY-102 Based on 1985 Core Sample.

\begin{tabular}{|c|c|c|}
\hline Analyte & $\begin{array}{c}1985 \text { core sample } \\
\text { concentrations }(\mu \mathrm{g} / \mathrm{g})\end{array}$ & Calculated inventory $(\mathrm{kg})$ \\
\hline $\mathrm{Ag}$ & $<1.77$ & $<0.806$ \\
\hline $\mathrm{Al}$ & 413 & 188 \\
\hline $\mathrm{Bi}$ & 39.8 & 18.1 \\
\hline $\mathrm{Cd}$ & $<4.42$ & $<2.01$ \\
\hline $\mathrm{Cr}$ & 57.6 & 26.2 \\
\hline $\mathrm{Fe}$ & 877 & 399 \\
\hline $\mathrm{Mn}$ & $<35.4$ & $<16.1$ \\
\hline $\mathrm{Na}$ & 206,000 & 93,800 \\
\hline $\mathrm{Ni}$ & $<16.5$ & $<7.51$ \\
\hline $\mathrm{NO}_{3}$ & 494,000 & 225,000 \\
\hline $\begin{array}{c}\mathrm{OH} \\
\text { (free hydroxide) }\end{array}$ & 0.510 & 0.232 \\
\hline $\mathrm{Pb}$ & $<63.8$ & $<29.1$ \\
\hline $\mathrm{P}$ as $\mathrm{PO}_{4}$ & 29,300 & 13,400 \\
\hline $\mathrm{Si}$ & 217 & 98.8 \\
\hline TOC & 327 & 149 \\
\hline $\mathrm{U}$ & 176 & 80.2 \\
\hline $\mathrm{Zr}$ & $<8.14$ & $<3.71$ \\
\hline Radionuclide $^{\mathrm{a}}$ & $\begin{array}{c}1985 \text { core sample } \\
\text { concentration }(\mu \mathrm{Ci} / \mathrm{g})\end{array}$ & Calculated inventory (Ci) \\
\hline${ }^{241} \mathrm{Am}$ & $<0.00475$ & $<2.16$ \\
\hline${ }^{14} \mathrm{C}$ & $<8.73$ E-04 & $<0.398$ \\
\hline${ }^{60} \mathrm{Co}$ & $<7.51$ E-04 & $<0.342$ \\
\hline${ }^{137} \mathrm{Cs}$ & 2.77 & 1,260 \\
\hline${ }^{129} \mathrm{I}$ & $<1.9 \mathrm{E}-05$ & $<0.00865$ \\
\hline${ }^{239 / 240} \mathrm{Pu}$ & 0.00142 & 0.65 \\
\hline${ }^{90} \mathrm{Sr}$ & 3.78 & 1,720 \\
\hline${ }^{99} \mathrm{Tc}$ & $<7.88 \mathrm{E}-04$ & $<0.359$ \\
\hline Density & $1.88 \mathrm{~g} / \mathrm{mL}$ & NA \\
\hline
\end{tabular}

NA $=$ not applicable

a Radionuclides decayed to January 1, 1994. 


\section{Revision 0}

A core sample was also obtained from tank 241-TY-102 in 1979 (Mitchell 1980). Details of the sample event were not located, but only one of the two core segments contained any sample when received at the laboratory (17.8 $\mathrm{cm}$ [7 in.] of extruded salt cake). The composition data reported by Mitchell was recalculated by Bratzel (1980). Although the sample does not represent the entire tank contents, the phosphate concentration reported by Bratzel was $228,000 \mu \mathrm{g} / \mathrm{g}$, which is much higher than that measured in the 1985 core sample. This may be an indication that the wastes are not uniformly distributed in tank 241-TY-102.

\section{D3.5 TANK 241-TY-102 CHEMICAL AND RADIONUCLDE INVENTORIES}

The tank 241-TY-102 chemical and radionuclide inventories estimated from the 242-T Evaporator salt cake layers and the 1985 core sample are tabulated in Table D3-5. The inventories estimated by the HDW model (Agnew et al. 1997a) are included in the table for comparison. All inventory estimates are based on a total waste volume of $242 \mathrm{~kL}$ $(64 \mathrm{kgal})$.

Table D3-5. Inventory Estimates for Tank 241-TY-102. (2 Sheets)

\begin{tabular}{|c|c|c|c|}
\hline Analyte & $\begin{array}{c}\text { Inventory based on } \\
\text { T1 and T2 salt cake } \\
\text { layers }^{\mathrm{a}}(\mathrm{kg})\end{array}$ & $\begin{array}{c}\text { Inventory based on } \\
\text { 1985 core sample } \\
(\mathrm{kg})\end{array}$ & $\begin{array}{c}\text { HDW model } \\
\text { inventory }(\mathrm{kg})\end{array}$ \\
\hline $\mathrm{Ag}$ & $<5.43$ & $<0.806$ & $\mathrm{NR}$ \\
\hline $\mathrm{Al}$ & 6,530 & 188 & 3,690 \\
\hline $\mathrm{Bi}$ & $<87.2$ & 18.1 & 391 \\
\hline $\mathrm{Ca}$ & 114 & $\mathrm{NR}$ & 543 \\
\hline $\mathrm{Cd}$ & $<2.56$ & $<2.01$ & $\mathrm{NR}$ \\
\hline $\mathrm{Cl}$ & 1,240 & $\mathrm{NR}$ & 1,060 \\
\hline $\mathrm{CO}$ & 16,200 & $\mathrm{NR}$ & 3,830 \\
\hline $\mathrm{Cr}$ & 309 & 26.2 & 577 \\
\hline $\mathrm{F}$ & 2,100 & $\mathrm{NR}$ & 383 \\
\hline $\mathrm{Fe}$ & 4,490 & 399 & 826 \\
\hline $\mathrm{Hg}$ & $\mathrm{NR}$ & $\mathrm{NR}$ & 0.362 \\
\hline $\mathrm{K}$ & $<427$ & $\mathrm{NR}$ & 284 \\
\hline $\mathrm{La}$ & $<15.1$ & $\mathrm{NR}$ & $1.49 \mathrm{E}-05$ \\
\hline $\mathrm{Mn}$ & 167 & $<16.1$ & 15.0 \\
\hline $\mathrm{Na}$ & 87,900 & 93,800 & 64,000 \\
\hline $\mathrm{Ni}$ & $<23.9$ & $<7.51$ & 115 \\
\hline
\end{tabular}




\section{Revision 0}

Table D3-5. Inventory Estimates for Tank 241-TY-102. (2 Sheets)

\begin{tabular}{|c|c|c|c|}
\hline Analyte & $\begin{array}{l}\text { Inventory based on } \\
\mathrm{T} 1 \text { and } \mathrm{T} 2 \text { salt cake } \\
\text { layers } \mathrm{s}^{\mathrm{a}}(\mathrm{kg})\end{array}$ & $\begin{array}{l}\text { Inventory based on } \\
1985 \text { core sample } \\
(\mathrm{kg})\end{array}$ & $\begin{array}{l}\text { HDW model } \\
\text { inventory }(\mathrm{kg})\end{array}$ \\
\hline $\mathrm{NO}_{2}$ & 7,350 & NR & 10,000 \\
\hline $\mathrm{NO}_{3}$ & 131,000 & 225,000 & 95,000 \\
\hline $\mathrm{OH}$ & 8,600 & NR & 14,900 \\
\hline $\mathrm{Pb}$ & $<109$ & $<29.1$ & 23.8 \\
\hline $\mathrm{P}$ as $\mathrm{PO}_{4}$ & 25,600 & 13,400 & 14,600 \\
\hline $\mathrm{Si}$ & 261 & 98.8 & 248 \\
\hline $\mathrm{SO}_{4}$ & 5,900 & NR & 3,540 \\
\hline $\mathrm{Sr}$ & $<4.44$ & NR & 0 \\
\hline TOC & 2,070 & 149 & 603 \\
\hline U & $<189$ & 80.2 & 2,090 \\
\hline $\mathrm{Zr}$ & 6.03 & $<3.71$ & 7.90 \\
\hline Radionuclide $^{c}$ & $\begin{array}{l}\text { Inventory based on } \mathrm{T} 1 \\
\text { and } \mathrm{T} 2 \text { salt cake layers } \\
\text { (Ci) }\end{array}$ & $\begin{array}{l}\text { Inventory based on } \\
1985 \text { core sample } \\
\text { (Ci) }\end{array}$ & $\begin{array}{l}\text { HDW model } \\
\text { inventory }(\mathrm{Ci})\end{array}$ \\
\hline${ }^{241} \mathrm{Am}$ & $<6,850$ & $<2.16$ & 5.03 \\
\hline${ }^{14} \mathrm{C}$ & NR & $<0.398$ & 2.69 \\
\hline${ }^{60} \mathrm{Co}$ & $<35.0$ & $<0.342$ & 2.91 \\
\hline${ }^{134} \mathrm{Cs}$ & 1.72 & NR & 0.211 \\
\hline${ }^{137} \mathrm{Cs}$ & 25,500 & 1,260 & 32,600 \\
\hline${ }^{154} \mathrm{Eu}$ & $<122$ & NR & 46.8 \\
\hline${ }^{155} \mathrm{Eu}$ & $<245$ & NR & 18.5 \\
\hline${ }^{129} \mathrm{I}$ & NR & $<0.00865$ & 0.0370 \\
\hline${ }^{239 / 240} \mathrm{Pu}$ & NR & 0.65 & 11.9 \\
\hline${ }^{90} \mathrm{Sr}$ & NR & 1,720 & 9,990 \\
\hline${ }^{99} \mathrm{Tc}$ & NR & $<0.359$ & 19.2 \\
\hline Density $(\mathrm{g} / \mathrm{mL})$ & 1.7 & 1.88 & 1.56 \\
\hline
\end{tabular}

HDW $=$ Hanford Defined Waste $\cdot$

$\mathrm{NR}=$ not reported

${ }^{\text {a }}$ Based on inventory calculated in Table D3-3

${ }^{b}$ Based on inventory calculated in Table D3-4

${ }^{c}$ Radionuclides decayed to January 1, 1994. 


\section{D3.6 COMPARISON OF TANK 241-TY-102 INVENTORY ESTIMATES}

The lack of recent core samples adds considerable uncertainty to estimation of chemical and radionuclide inventories for tank 241-TY-102. The use of the 1985 core sample data and the waste composition data from tanks 241-T-108, 241-T-109, 241-TX-116, 241-U-102, and 241-U-105 to represent the wastes in tank 241-TY-102 is a reasonable approach in the absence of a more recent core sample. However, it should be noted that the operating history of tank 241-TY-102 is different from any other Hanford Site tank containing similar waste types. The estimates which are based on compositions measured in other tanks should be regarded only as approximations.

The tank 241-TY-102 inventories predicted by the HDW model are quite different from those based on the 1985 core sample of tank 241-TY-102 (see Table D3-5). The sample-based sodium and nitrate inventories are much higher than the HDW model prediction, although the phosphate inventories are comparable. Part of the explanation for this difference may be that the HDW model calculated density for the tank 241-TY-102 T2 salt cake is $1.40 \mathrm{~g} / \mathrm{cc}$ based on the sodium, aluminum, and hydroxide concentrations. The average measure salt cake densities for tanks $241-\mathrm{U}-102$ and $241-\mathrm{U}-105$ was $1.7 \mathrm{~g} / \mathrm{mL}$. The HDW model calculated density is used in determining the inventory of all analytes in the T2 salt cake layer. The radionuclide inventories predicted by the HDW model are consistently higher than those calculated from analytical results.

Aluminum. The aluminum inventory based on the 1985 core sample is only about 5 percent of that predicted by the HDW model. Most of the aluminum associated with 242-T Evaporator wastes is present in the T2 salt cakes. The free hydroxide concentration found in the tank 241-TY-102 waste was very low. One possible explanation for this low aluminum inventory is that the aluminum was precipitated in the preceding tanks in the evaporator bottoms loop due to low free hydroxide concentrations. Tank 241-TY-102 did not directly receive evaporator bottoms from the 242-T Evaporator. The aluminum inventory calculated from the 1985 core sample will be used for the best-basis inventory.

Carbonate and Hydroxide. The tank 241-TY-102 carbonate inventory estimated from the salt cake layers in other tanks was 4.2 times the HDW model inventory. The hydroxide ion in Hanford Site waste tanks is converted to carbonate by the absorption of carbon dioxide from the ambient air. One mole of absorbed carbon dioxide will react with two moles of hydroxide ion to form one mole of carbonate ion. The rate is difficult to model, and is accelerated by use of airlift circulators installed in many Hanford Site underground storage tanks. Conversion of $7,020 \mathrm{kgs}$ of hydroxide to carbonate would account for the difference. The HDW model does not account for the absorption of carbon dioxide from the atmosphere.

Fluoride . The fluoride inventory estimated from salt cake layers in other tanks is 5.5 times that predicted by the HDW model. This is possibly the result of the HDW model assumptions that sodium fluoride is the only chemical compound containing fluoride and that it does not precipitate. The formation of insoluble fluoride compounds (such as sodium fluorophosphate) may be causing some fluoride to precipitate and remain in the tank. 
Iron. The iron inventory based on the 1985 core sample is 48 percent of that predicted by the HDW model. Tank 241-TY-102 received primarily salt cake supernatants and only a small volume of TBP supernatant, so the low iron concentration is reasonable. The estimated iron inventory estimated from the salt cake layers in other tanks is skewed by the high iron concentration (2.4 wt\% on silicon-free basis) reported for the tank 241-TX-116 T2 salt cake. A high iron concentration is not likely for a salt cake since iron is insoluble in alkaline solutions and significant iron concentration would not be expected in the evaporator feed solutions. The inventory calculated from the 1985 core sample will be used for the best basis.

Nitrate. The nitrate inventory was reduced to $150,000 \mathrm{~kg}$ as the result of the charge balance calculation. The revised inventory is still 1.6 times that predicted by the HDW model. The HDW model T2 salt cake inventory is predicted by the SMM, and it is, therefore, difficult to fully determine the cause of this discrepancy. The low T2 salt cake density calculated by the HDW model would explain part of this difference, but the nitrate concentration predicted by the HDW model also appears to be low $(168,000 \mu \mathrm{g} / \mathrm{g})$. The global HDW model T2 salt cake concentrations (see Table D3-2) are very reasonable, indicating that either the problem lies within the SMM model or that some feed inputs have been missed.

Phosphate. The phosphate inventory calculated from the 1985 core sample is in good agreement with the HDW model (within 10 percent).

Sodium. The predicted HDW sodium inventory is about 68 percent of that calculated from the analytical results for the 1985 core sample. The waste density predicted by the HDW model for the T2 salt slurry is $1.40 \mathrm{~g} / \mathrm{cc}$, which is 18 percent below that normally expected for a T2 salt cake based on the analyses of the U Tank Farm tanks. The remainder of the difference is the result of the low sodium concentration $(153,000 \mu \mathrm{g} / \mathrm{g})$ predicted for the T2 salt cake layer by the SMM. The global HDW model T2 salt cake sodium concentration is very reasonable (see Table D3-2). Either there is an internal problem in the SMM model calculations or some feed inputs have been missed.

Total Hydroxide. Once the best-basis inventories were determined, the hydroxide inventory was calculated by performing a charge balance with the valences of the other analytes. In some cases, this approach requires that other analyte (e.g., sodium or nitrate) inventories be adjusted to achieve the charge balance. During such adjustments, the number of significant figures is not increased. The charge balance approach is consistent with that used by Agnew et al. (1997a). The initial total hydroxide inventory calculation resulted in a negative hydroxide ion concentration. The best-basis nitrate inventory was reduced to $150,000 \mathrm{~kg}$ since anion analyses are generally less reliable than those for cations, and the reported nitrate concentration was much higher than the other estimates. The recalculated total hydroxide concentration is $5,510 \mathrm{~kg}$, which is reasonable considering the low free hydroxide reported for the 1985 core sample. 
Cesium-137 and Strontium-90. The heat load for tank 241-TY-102 has been estimated at $2,712 \mathrm{BTU} / \mathrm{h}$ (Kummerer 1995). This corresponds to a maximum of $119,000 \mathrm{Ci}$ ${ }^{90} \mathrm{Sr}\left(0.0228 \mathrm{BTU} / \mathrm{h} / \mathrm{Ci}{ }^{90} \mathrm{Sr}\right)$ or a maximum of $168,000 \mathrm{Ci}{ }^{137} \mathrm{Cs}\left(0.0161 \mathrm{BTU} / \mathrm{h} / \mathrm{Ci}{ }^{137} \mathrm{Cs}\right)$. The sample-based radionuclide estimate accounts for only 2.1 percent of this estimated heat load. The HDW model radionuclide inventories would account for only 28 percent of the heat load. Since tank 241-TY-102 waste volume is small and consists only of salt cake, the heat load estimate appears to be in error. The ${ }^{90} \mathrm{Sr}$ and ${ }^{137} \mathrm{Cs}$ inventories calculated from the 1985 core sample will be used for the best-basis. 
HNF-SD-WM-ER-719

Revision 0

\section{D4.0 DEFINE THE BEST-BASIS AND ESTABLISH COMPONENT INVENTORIES}

Information about chemical, radiological, and/or physical properties is used to perform safety analyses, engineering evaluations, and risk assessment associated with waste management activities, as well as regulatory issues. 'These activities include overseeing tank farm operations and identifying, monitoring, and resolving safety issues associated with these operations and with the tank wastes. Disposal activities involve designing equipment, processes and facilities for retrieving wastes and processing them into a form that is suitable for long-term storage.

Chemical and radiological inventory information are generally derived using three approaches: (1) component inventories are estimated using the results of sample analyses, (2) component inventories are predicted using the HDW model based on process knowledge and historical information, or (3) a tank-specific process estimate is made based on process flowsheets, reactor fuel data, essential material usage, and other operating data.

An effort is underway to provide waste inventory estimates that will serve as the standard characterization for the various waste management activities (Hodgson and LeClair 1996): As part of this effort, an evaluation of available information for tank 241-TY-102 was performed including the following:

- Waste transactions and operating data to confirm that only 242-T Evaporator salt cakes were expected in this tank.

- Composition data from three waste tanks (241-T-108, 241-T-109, and 241-TX-116) which are expected to have a similar T1 salt cake compositions, and three waste tanks (241-U-102, 241-U-105, and 241-TX-116) that are expected to have similar $\mathrm{T} 2$ salt cake compositions.

- A 1985 core sample of the tank 241-TY-102 waste (Weiss and Mauss 1987a).

- An inventory estimate generated by the HDW model (Agnew et al. 1997a)

Based on this evaluation, a best-basis inventory was developed. No recent analytical data are available for the salt cake remaining in tank 241-TY-102 because no core samples have been taken since 1985 . The estimated inventory was, therefore, based on the analytical data reported for the 1985 core sample, the composition of $\mathrm{T} 1$ salt cakes in tanks 241-T-108, 241-T-109, and 241-TX-116, and the composition of T2 salt cakes in tanks 241-U-102, 241-U-105, and 241-TX-116. The HDW model inventories were used when no other data were available or when analytical data were suspect.

The waste in tank 241-TY-102 consists of $242 \mathrm{~kL}$ (64 kgal) of T1 and T2 salt cake produced by the 242-T Evaporator. The best-basis inventory for tank 241-TY-102 is presented in Tables D4-1 and D4-2. The inventory values reported in Tables D4-1 and D4-2 
are subject to change. Refer to the Tank Characterization Database (TCD) for the most current inventory values.

Best-basis tank inventory values are derived for 46 key radionuclides (as defined in Section 3.1 of Kupfer et al. 1997), all decayed to a common report date of January 1, 1994. Often, waste sample analyses have only reported ${ }^{90} \mathrm{Sr},{ }^{137} \mathrm{Cs},{ }^{239 / 240} \mathrm{Pu}$, and total uranium (or total beta and total alpha), while other key radionuclides such as ${ }^{60} \mathrm{Co},{ }^{99} \mathrm{Tc},{ }^{129} \mathrm{I},{ }^{154} \mathrm{Eu},{ }^{155} \mathrm{Eu}$, and ${ }^{241} \mathrm{Am}$, etc., have been infrequently reported. For this reason it has been necessary to derive most of the 46 key radionuclides by computer models. These models estimate radionuclide activity in batches of reactor fuel, account for the split of radionuclides to various separations plant waste streams, and track their movement with tank waste transactions. (These computer models are described in Kupfer et al. 1997, Section 6.1 and in Watrous and Wootan 1997.) Model generated values for radionuclides in any of 177 tanks are reported in the Hanford Defined Waste Rev. 4 model results (Agnew et al. 1997a). The best-basis value for any one analyte may be either a model result or a sample or engineering assessment-based result if available. (No attempt has been made to ratio or normalize model results for all 46 radionuclides when values for measured radionuclides disagree with the model.) For a discussion of typical error between model derived values and sample derived values, see Kupfer et al. 1997, Section 6.1.10.

Table D4-1. Best-Basis Inventory Estimates for Nonradioactive Components in Tank 241-TY-102 (Effective May 31, 1997). (2 Sheets)

\begin{tabular}{|c|c|c|l|}
\hline Analyte & $\begin{array}{c}\text { Total } \\
\text { inventory } \\
(\mathrm{kg})\end{array}$ & $\begin{array}{c}\text { Basis } \\
(\mathrm{S}, \mathrm{M}, \mathrm{E}, \text { or C })^{1}\end{array}$ & Comment \\
\hline $\mathrm{Al}$ & 188 & $\mathrm{~S}$ & \\
\hline $\mathrm{Bi}$ & 18.1 & $\mathrm{~S}$ & \\
\hline $\mathrm{Ca}$ & 114 & $\mathrm{E}$ & \\
\hline $\mathrm{Cl}$ & 1,240 & $\mathrm{E}$ & \\
\hline $\mathrm{CO}_{3}$ & 16,200 & $\mathrm{E}$ & \\
\hline $\mathrm{Cr}$ & 26.2 & $\mathrm{~S}$ & \\
\hline $\mathrm{F}$ & 2,100 & $\mathrm{E}$ & \\
\hline $\mathrm{Fe}$ & 399 & $\mathrm{~S}$ & \\
\hline $\mathrm{Hg}$ & 0.362 & $\mathrm{M}$ & \\
\hline $\mathrm{K}$ & 427 & $\mathrm{E}$ & \\
\hline $\mathrm{La}$ & $1.49 \mathrm{E}-05$ & $\mathrm{M}$ & \\
\hline $\mathrm{Mn}$ & $<16.1$ & $\mathrm{~S}$ & \\
\hline $\mathrm{Na}$ & 93,800 & $\mathrm{~S}$ & \\
\hline $\mathrm{Ni}$ & $<7.51$ & $\mathrm{~S}$ & \\
\hline
\end{tabular}


HNF-SD-WM-ER-719

Revision 0

Table D4-1. Best-Basis Inventory Estimates for Nonradioactive Components in Tank 241-TY-102 (Effective May 31, 1997). (2 Sheets)

\begin{tabular}{|c|c|c|c|}
\hline Analyte & $\begin{array}{c}\text { Total } \\
\text { inventory } \\
(\mathrm{kg})\end{array}$ & $\begin{array}{c}\text { Basis } \\
(\mathrm{S}, \mathrm{M}, \mathrm{E}, \text { or } \mathrm{C})^{1}\end{array}$ & Comment \\
\hline $\mathrm{NO}_{2}$ & 7,350 & $\mathrm{E}$ & \\
\hline $\mathrm{NO}_{3}$ & 150,000 & $\mathrm{C}$ & $\begin{array}{l}\text { Sample-based nitrate inventory was } \\
225,000 \mathrm{~kg} \text { before adjustment. } \\
\text { Concentration varies significantly } \\
\text { between } \mathrm{T} 1 \text { salt cakes. }\end{array}$ \\
\hline $\mathrm{OH}$ & 5,490 & $\mathrm{C}$ & Estimated by ion charge balance. \\
\hline $\mathrm{Pb}$ & $<29.1$ & $S$ & \\
\hline $\mathrm{P}$ as $\mathrm{PO}_{4}$ & 13,400 & $S$ & $\begin{array}{l}\text { Concentration varies significantly } \\
\text { between } \mathrm{T} 1 \text { salt cakes. }\end{array}$ \\
\hline $\mathrm{Si}$ & 98.8 & $S$ & \\
\hline $\mathrm{S}$ as $\mathrm{SO}_{4}$ & 5,900 & $\mathrm{E}$ & \\
\hline $\mathrm{Sr}$ & $<4.44$ & $E$ & \\
\hline TOC & 149 & $S$ & \\
\hline$U_{\text {TOTAL }}$ & 80.2 & $S$ & \\
\hline $\mathrm{Zr}$ & $<3.71$ & $S$ & \\
\hline \multicolumn{4}{|r|}{ oxides as hydroxides, not including } \\
\hline
\end{tabular}




\section{Revision 0}

Table D4-2. Best-Basis Inventory Estimates for Radioactive Components in Tank 241-TY-102 Decayed to January 1, 1994 (Effective May 31, 1997). (2 Sheets)

\begin{tabular}{|c|c|c|c|}
\hline Analyte & $\begin{array}{c}\text { Total inventory } \\
\text { (Ci) }\end{array}$ & $\begin{array}{c}\text { Basis } \\
(\mathrm{S}, \mathrm{M} \text {, or } \mathrm{E})^{1} \\
\end{array}$ & Comment \\
\hline${ }^{3} \mathrm{H}$ & 18.9 & $\mathbf{M}$ & \\
\hline${ }^{14} \mathrm{C}$ & $<0.398$ & $S$. & \\
\hline${ }^{59} \mathrm{Ni}$ & 0.301 & M & \\
\hline${ }^{60} \mathrm{Co}$ & $<0.342$ & $S$ & \\
\hline${ }^{63} \mathrm{Ni}$ & 28.7 & M & \\
\hline${ }^{79} \mathrm{Se}$ & 0.282 & $\mathbf{M}$ & \\
\hline${ }^{90} \mathrm{Sr}$ & 1,720 & $S$ & \\
\hline${ }^{90} \mathrm{Y}$ & 1,720 & $\mathrm{E}$ & Based on ${ }^{90} \mathrm{Sr}$ concentration. \\
\hline${ }^{93} \mathrm{Zr}$ & 1.38 & $\mathrm{M}$ & \\
\hline${ }^{93 m} \mathrm{Nb}$ & 1.01 & $\mathrm{M}$ & \\
\hline${ }^{99} \mathrm{Tc}$ & $<0.359$ & $S$ & \\
\hline${ }^{106} \mathrm{Ru}$ & $5.18 \mathrm{E}-04$ & $\mathrm{M}$ & \\
\hline${ }^{113 \mathrm{~m}} \mathrm{Cd}$ & 7.01 & $\mathrm{M}$ & \\
\hline${ }^{125} \mathrm{Sb}$ & 12.3 & $\mathbf{M}$ & \\
\hline${ }^{126} \mathrm{Sn}$ & 0.426 & M & \\
\hline${ }^{129} \mathbf{I}$ & $<0.00865$ & $S$ & \\
\hline${ }^{134} \mathrm{Cs}$ & 0.211 & $\mathrm{M}$ & \\
\hline${ }^{137} \mathrm{Cs}$ & 1,260 & $S$ & \\
\hline${ }^{137 \mathrm{~m}} \mathrm{Ba}$ & 1,190 & $\mathrm{E}$ & Based on ${ }^{137} \mathrm{Cs}$ concentration. \\
\hline${ }^{151} \mathrm{Sm}$ & 996 & M & \\
\hline${ }^{152} \mathrm{Eu}$ & 0.308 & M & \\
\hline${ }^{154} \mathrm{Eu}$ & 46.8 & $\mathrm{M}$ & . \\
\hline${ }^{155} \mathrm{Eu}$ & 18.5 & M & \\
\hline${ }^{226} \mathrm{Ra}$ & $1.59 \mathrm{E}-05$ & M & \\
\hline${ }^{227} \mathrm{Ac}$ & 1.00 E-04 & $\mathrm{M}$ & . \\
\hline${ }^{228} \mathrm{Ra}$ & 0.0215 & $\mathrm{M}$ & \\
\hline${ }^{229} \mathrm{Th}$ & $4.98 \mathrm{E}-04$ & $\mathrm{M}$ & \\
\hline${ }^{231} \mathrm{~Pa}$ & $4.08 \mathrm{E}-04$ & M & \\
\hline
\end{tabular}


HNF-SD-WM-ER-719

Revision 0

Table D4-2. Best-Basis Inventory Estimates for Radioactive Components in Tank 241-TY-102 Decayed to January 1, 1994 (Effective May 31, 1997). (2 Sheets)

\begin{tabular}{|c|c|c|l|}
\hline Analyte & $\begin{array}{c}\text { Total inventory } \\
(\mathrm{Ci})\end{array}$ & $\begin{array}{c}\text { Basis } \\
(\mathrm{S}, \mathrm{M}, \text { or } \mathrm{E})\end{array}$ & Comment \\
\hline${ }^{232} \mathrm{Th}$ & 0.00132 & $\mathrm{M}$ & \\
\hline${ }^{232} \mathrm{U}$ & 0.108 & $\mathrm{M}$ & \\
\hline${ }^{233} \mathrm{U}$ & 0.412 & $\mathrm{M}$ & \\
\hline${ }^{234} \mathrm{U}$ & 0.699 & $\mathrm{M}$ & \\
\hline${ }^{235} \mathrm{U}$ & 0.0306 & $\mathrm{M}$ & \\
\hline${ }^{236} \mathrm{U}$ & 0.00857 & $\mathrm{M}$ & \\
\hline${ }^{237} \mathrm{~Np}$ & 0.0703 & $\mathrm{M}$ & \\
\hline${ }^{238} \mathrm{Pu}$ & 0.15 & $\mathrm{M}$ & \\
\hline${ }^{238} \mathrm{U}$ & 0.728 & $\mathrm{M}$ & \\
\hline${ }^{239240} \mathrm{Pu}$ & 0.65 & $\mathrm{~S}$ & \\
\hline${ }^{241} \mathrm{Am}$ & $<2.16$ & $\mathrm{~S}$ & \\
\hline${ }^{241} \mathrm{Pu}$ & 8.69 & $\mathrm{M}$ & \\
\hline${ }^{242} \mathrm{Cm}$ & 0.0116 & $\mathrm{M}$ & \\
\hline${ }^{242} \mathrm{Pu}$ & $4.59 \mathrm{E}-05$ & $\mathrm{M}$ & \\
\hline${ }^{243} \mathrm{Am}$ & $1.67 \mathrm{E}-04$ & $\mathrm{M}$ & \\
\hline${ }^{243} \mathrm{Cm}$ & 0.00107 & $\mathrm{M}$ & \\
\hline${ }^{244} \mathrm{Cm}$ & 0.011 & $\mathrm{M}$ & \\
\hline${ }^{1} \mathrm{~S}=$ & & \\
\hline
\end{tabular}

${ }^{1} \mathrm{~S}=$ Sample-based

$M=$ Hanford Defined Waste model-based

$\mathrm{E}=$ Engineering assessment-based. 
HNF-SD-WM-ER-719

Revision 0

This page intentionally left blank. 
HNF-SD-WM-ER-719

Revision 0

\section{D5.0 APPENDIX D REFERENCES}

Agnew, S. F., J. Boyer, R. A. Corbin, T. B. Duran, J. R. FitzPatrick, K. A. Jurgensen, T. P. Ortiz, and B. L. Young, 1997a, Hanford Tank Chemical and Radionuclide Inventories: HDW Model Rev. 4, LA-UR-96-3860, Los Alamos National Laboratory, Los Alamos, New Mexico.

Agnew, S. F., R. A. Corbin, T. B. Duran, K. A. Jurgensen, T. P. Ortiz, and B. L. Young, 1997b, Waste Status and Transaction Record Summary (WSTRS Rev. 4), LA-UR-97-311, Rev. 0, Los Alamos National Laboratory, Los Alamos, New Mexico.

Allen, G. K., 1977, Salt Cake and Sludge Characterization Program 24I-TX-116 Hot Test and Subsequent Cold Test Results, RHO-CD-3, Rockwell Hanford Operations, Richland, Washington.

Anderson, J. D., 1990, A History of the 200 Area Tank Farms, WHC-MR-0132, Westinghouse Hanford Company, Richland, Washington.

Baldwin, J. H., 1996, Tank Characterization Report for Single-Shell Tank 241-T-108, WHC-SD-WM-ER-554, Rev. 0-A, Westinghouse Hanford Company, Richland, Washington.

Bratzel, D. R., 1980, Evaluation of Waste Storage Tank Physical and Chemical Characterization Data, Internal Memo 65453-80-265 to F. M. Jungfleisch, Rockweil Hanford Operations, Richland Washington.

Brown, T. M., L. M. Sasaki, R. D. Cromar, N. G. Colton, J. L. Stroup, J. D. Franklin, and L. J. Fergestrom, 1996, Tank Characterization Report for Single-Shell Tank 241-T-109, WHC-SD-WM-ER-559, Rev. 0, Westinghouse Hanford Company, Richland Washington.

Brown, T. M., and J. Franklin, 1996, Tank Characterization Report for Single-Shell Tank 24I-U-105, WHC-SD-WM-ER-617, Rev. 0, Westinghouse Hanford Company, Richland, Washington.

Buckingham, J. S., and W. P. Metz, 1974, Characterization of the Effects of Diatomaceous Earth Additions to Hanford Wastes, ARH-CD-222, Atlantic Richfield Hanford Company, Richland, Washington.

Hanlon, B. M., 1997, Waste Tank Summary Report for Month Ending February 28, 1997, HNF-EP-0182-107, Lockheed Martin Hanford Corporation, Richland, Washington. 
HNF-SD-WM-ER-719

Revision 0

Hill, J. G., G. S. Anderson, and B. C. Simpson, 1995, The Sort on Radioactive Waste Type Model: A Method to Sort Single-Shell Tanks into Characteristic Groups, PNL-9814, Rev. 2, Pacific Northwest Laboratory, Richland, Washington.

Hodgson, K. M., and M. D. LeClair, 1996, Work Plan for Defining A Standard Inventory Estimate for Wastes Stored in Hanford Site Underground Tanks, WHC-SD-WM-WP-311, Rev. 1, Lockheed Hanford Company, Richland, Washington.

Horton, J. E., 1977, Physical and Chemical Characterization of Tank 116-TX, Letter to G. K. Allen, Atlantic Richfield Hanford Company, Richland, Washington.

Hu, T. A., L. C. Amato, R. T. Winward, and R. D. Cromar, 1997, Tank Characterization Report for Single-Shell Tank 241-U-102, WHC-SD-WM-ER-618, Rev. 0, Lockheed Martin Hanford Company, Richland, Washington.

Kummerer, M., 1995, Heat Removal Characteristics of Waste Storage Tanks, WHC-SD-WM-SARR-010, Rev. 1, Westinghouse Hanford Company, Richland, Washington.

Kupfer, M. J., A. L. Boldt, B. A. Higley, K. M. Hodgson, L. W. Shelton, and R. A. Watrous (LMHC), S. L. Lambert, and D. E. Place (SESC), R. M. Orme (NHC), G. L. Borsheim (Borsheim Associates), N. G. Colton (PNNL), M. D. LeClair (SAIC), R. T. Winward (Meier Associates), and W. W. Schulz (W²S Corporation), 1997, Standard Inventories of Chemicals and Radionuclides in Hanford Site Tank Wastes, HNF-SD-WM-TI-740, Rev. 0, Lockheed Martin Hanford Corporation, Richland, Washington.

Mitchell, M. E., 1980, Physical and Chemical Characteristics of Tanks 105-TY, 103-TY, and 102-TY, Internal Merno 65124-80-077 to D. J. Flesher, Rockwell Hanford Operations, Richland, Washington.

Watrous, R. A., and D. W. Wootan, 1997, Activity of Fuel Batches Processed Through Hanford Separations Plants, 1944 Through 1989, HNF-SD-WM-Tl-794, Rev. 0, Lockheed Martin Hanford Corporation, Richland, Washington.

Weiss, R. L., and B. M. Mauss, 1987a, Data Transmittal Package for 241-TY-102 Waste Tank Characterization, SD-RE-TI-183, Rev. 0, Rockwell Hanford Operations, Richland Washington.

Weiss, R. L., and B. M. Mauss, 1987b, Data Transmittal Package for 241-TY-101 Waste Tank Characterization, SD-RE-TI-185, Rev. 0, Rockwell Hanford Operations, Richland Washington. 